\title{
Application Development for Assessing the Health Level of Village Credit Institutions Using the RGEC Method
}

\author{
Jeni Susanti*, I Gede Made Karma, Ni Wayan Kurnia Dewi \\ Accounting Department \\ Politeknik Negeri Bali \\ Badung, Indonesia \\ *susanti@pnb.ac.id, igmkarma@pnb.ac.id, wayankurniadewi@pnb.ac.id
}

\begin{abstract}
The Covid 19 pandemic turned out to have an impact on the economic downturn of the community. The Village Credit Institution (LPD), a financial institution belonging to a traditional village in Bali, is greatly affected by this situation. The management team is required to be able to maintain the health level of the LPD in the midst of the economic crisis with the risk of liquidity difficulties and bad credit at this time. This study aims to build an information system for LPD health level assessors. The system was developed with an object oriented methodology, with the LPD health assessor using the RGEC method. The method, which includes the Risk Profile (R), Good Corporate Government (G), Earnings (E) and Capital (C) factors, does consider the problem of risk. Based on financial report data and self-assessment results related to LPD management, the resulting system will determine the LPD's health level quickly, precisely and at any time. The resulting health level is in the form of a comprehensive and partial health level according to the factors, to make it easier for the management team to determine the focus of the study and analysis if a problem occurs in the LPD health level.
\end{abstract}

Keywords-LPD, economic crisis, health level, RGEC method

\section{INTRODUCTION}

Currently, the world community is faced with difficult and uncertain situations, due to the Covid 19 pandemic. In addition to threatening health, this situation also affects the economic level of the community. Regional restrictions or large-scale social restrictions programs implemented by various countries have an impact on the limitations of people traveling outside the home. As a result, many businesses that depend their lives from visiting people, such as hotels, restaurants, shops and others are closed. Many employees are laid off, laid off or work part time with incomplete salaries. There are even some people who do not have any more income due to this pandemic.

The decline or even loss of income earned by the business world or society in general, of course also has an impact on decreasing or losing their ability to fulfill their obligations. Never mind fulfilling the obligation to pay debts, just to maintain life, felt difficult by some people. For people who have savings or deposits, they will try to withdraw their savings or deposits to make ends meet. Such a situation is certainly hitting financial institutions such as banks, cooperatives or credit institutions that have provided loans to the public. The inability of the people to pay their credit certainly has the potential to make the credit bad [1]. On the other hand, this institution is demanded to be able to maintain its liquidity in the midst of the large interest of the public to withdraw their savings. Mistakes in handling this problem are of course very risky to the survival of this financial institution. The economic condition of a country is greatly influenced by the soundness of the financial institutions in that country. The decline in the soundness of financial institutions will disrupt economic conditions, particularly in the state financial system. Therefore, the government has an interest in maintaining and improving the soundness of these financial institutions [2].

Banks are financial intermediary institutions established as fund collectors and channeling funds for the public. Bank health is the ability of banks to carry out their activities formally and the ability to fulfill all their responsibilities and comply with banking regulations [3,4]. Managers are required to know the soundness level of the financial institutions they manage. This level of health is directly related to the competitiveness of the financial institutions themselves. Apart from internal purposes, external parties also need information related to the financial position of the institution, which is reflected in its soundness level $[5,6]$. To maintain a healthy financial system, it is mandatory to analyze banks periodically to find out their strengths and eliminate potential vulnerabilities [7]. Various methods have been developed to determine the soundness level of financial institutions, such as the CAMEL method, RGEC, the Takagi-Sugeno-Kang (TSK) fuzzy zeroorder and the Risk Based Bank Rating. Each method uses certain indicators by taking into account different factors and conditions. RGEG implementation which includes risk, good corporate governance, income, and capital, is more implemented to measure and determine the determinants of a bank's profit growth rate [8]. Good corporate governance, 
income, capital and management have a significant positive effect on soundness [9]. The Takagi-Sugeno-Kang (TSK) zeroorder fuzzy model is applied to build a fuzzy rule that can improve the accuracy of the analysis results of a bank's performance level, when applied with the RGEC model [10]. Meanwhile, to measure the risk level of a bank can be done by applying the Risk Based Bank Rating. Measurements are made based on the level of the bank's total assets, loans and trading assets [11].

In an effort to protect the banking sector which is highly vulnerable to economic crisis, Bank Indonesia has taken a strategic step, namely by changing the method for determining the soundness level of a bank. Based on Bank Indonesia Regulation no.13 / 1 / PBI / 2011 concerning ratings of commercial banks, banks are required to conduct bank assessments based on Risk Based Bank Assessments [12,13]. The stages of bank RGEC assessment can be called a bank health assessment model that is loaded with risk management $[14,15]$. The selection of the RGEC method is based more on the suitability of this method being applied to assess the level of risk experienced by a bank in a financial crisis situation such as the current one. Innovations in banking products, services and activities that are not balanced with the application of the adequacy of Risk Management can cause various fundamental problems with banks and the financial system as a whole. In addition, the failure of top management strategies and fraud practices also occurs undetected and causes the importance of implementing good corporate governance [16]. Knowing the soundness of banking is expected to increase public confidence so that it can increase public investment in banks that can directly support Indonesia's economic growth [17,18]. The health or financial and non-financial condition of a bank is for the benefit of all related parties, including the owner, manager (management) of the bank, the public who use the services of the bank (customer) and Bank Indonesia as the supervisory authority of the bank and other parties [19].

Every traditional village in Bali generally has a business entity in the form of a financial institution called the Village Credit Institution (LPD). Because it belongs to a customary village, the LPD's operational area is limited to the area of the customary village concerned [20]. The formation and management of this LPD is regulated through a Bali Level 1 Regional Regulation. The main activity of the LPD is collecting funds from indigenous villages through various types of savings products and channeling them back to the community through disbursement of credit. Part of the profits, according to policy, are reinvested in society and members actively participate in determining the use of surpluses [21]. The management and institutional arrangements of an LPD cannot be separated from the prevailing customary rules. Social norms and customary sanctions have always been a reference in determining policies. In determining operational policies, the customary village head is actively involved in it [22,23]. In general, LPDs are performing well and are sustainable. This can be seen from the achievements of various performance indicators including financial and outreach indicators. The majority of LPDs have financial indicators that are indicated by good portfolio quality, leverage, capital adequacy ratio, productivity, efficiency, profitability, and financial feasibility. In terms of coverage, it can be said that LPDs really control the operational area [24].

The economic crisis of the community due to the existence of this pandemic can of course have an impact on the health level of the LPD. Institutionally, determining the level of LPD health has been determined using the CAMEL method [25]. In this risky situation, knowing the health level of risk-based LPDs becomes a necessity. This research is intended to produce an information system that can be used by the LPD to assess the level of health in real time and up to date. LPD health indicators are calculated using the RGEC method.

\section{LITERATURE REVIEW}

Financial analysis is an analytical technique that connects one item with another item either in the balance sheet or income statement or a combination of both reports. The results of this financial analysis are financial ratios. There are various kinds of ratios that can be calculated from the financial statement data available. The ratio selection is determined based on the type of assessment carried out and the type of company [26]. The selected ratio can later be used to determine the level of financial soundness of the company concerned. Financial ratios will provide an overview of the company's financial condition, such as the high / low level of expenditure and the level of corporate debt, or the good / bad level of receivables collection [27]. The ratio can also be used as a basis by management in the decision making process and future policies [28].

The application of a risk based approach (Risk Based Bank Rating) to assess the soundness of a bank is a comprehensive and structured assessment. The assessment is carried out in an integrated manner between risk profile and performance. Performance is assessed based on the results of the implementation of good governance, profitability and capital [29]. RGEC method is a method to determine the soundness of a bank which includes an assessment of the Risk Profile, Good Corporate Governance (GCG), Earning, and Capital factors [30,31]. Assessment of risk profile factors is associated with how the application of risk management in companies, GCG factors are associated with the existence and implementation of corporate governance, earning factors are associated with the company's ability to make profits and the Capital factor is associated with capital adequacy owned by companies [32,33].

The assessment of bank soundness is an assessment of RGEC factors on risk profile, good corporate governance, income, and capital [34]. In the aspect of Risk Profile carried out by analyzing the Credit Risk represented by the NPL ratio, it is considered healthy, while the analysis of Liquidity Risk represented by the LDR ratio is also considered healthy. Furthermore, from the aspect of Good Corporate Governance (GCG), the bank's performance is considered very healthy. The overall financial performance from the Earning aspect which is calculated by analyzing the ratio of NIM and ROA is also 
considered healthy. Finally, the overall financial performance of the Capital aspect is calculated by analyzing the comparison between the ratio of capital to Risk Weighted Assets (RWA) represented by the CAR ratio considered healthy $[35,36]$.

\section{A. Risk Profile}

The risk profile factor is measured by using indicators in the form of credit risk and liquidity risk. Each of these risks is determined by using a Non Performing Loan (NPL) ratio and a Loan to Deposit Ratio (LDR) ratio. NPLs are categorized into three groups, substandard, doubtful, and loss. The higher the NPL level, the greater the credit risk carried by the bank. LDR is a useful instrument for determining bank liquidity, and in turn, it affects bank profitability [37]. Both ratios are determined by (1) and (2).

$$
\begin{aligned}
& \text { NPL }=\frac{\text { Non Performing Loan }}{\text { Total Loan }} \times 100 \% \\
& \text { LDR }=\frac{\text { Total Debt }}{\text { Third Parties Fund }} \times 100 \%
\end{aligned}
$$

\section{B. Good Corporate Governance (GCG)}

Referring to Bank Indonesia Circular Number 15/15 / DPNP dated 29 April 2013 concerning the Implementation of Good Corporate Governance, the determination of GCG factors is done by self-assessment. The assessment is carried out covering 3 (three) aspects, namely governance structure, governance process, and governance outcome, which is carried out comprehensively and structurally. The GCG assessment factor is an assessment of the quality of bank management on the application of GCG principles [38]. Quality management is an important key in maintaining bank health [39].

\section{Earning}

The income factor is considered to be related to various factors related to profitability and sustainability [40]. For this aspect of profitability, what is assessed is the ability of banks to increase profits and business efficiency achieved [41]. Profitability factor is measured by using the ratio of Return on Assets (ROA) and Net Interest Margin (NIM). These two ratios can be calculated using (3) and (4).

$$
\begin{aligned}
\mathrm{ROA} & =\frac{\text { Net Income }}{\text { Total Assets }} \times 100 \% \\
\mathrm{NIM} & =\frac{\text { Invetsment Return }- \text { Interest Expenses }}{\text { Average Earnings Assets }} \times 100 \%
\end{aligned}
$$

\section{Capital}

The capital factor is measured by using the Capital Adequacy Ratio (CAR), which is the capital adequacy ratio that is useful to accommodate the risk of loss that may be faced by banks [42]. CAR indicates the extent to which banks contain risks (credit, statements, securities, invoices) which are financed by public funds [43], which can be calculated by (5).

$$
\text { CAR }=\frac{\text { Tier } 1 \text { Capital }- \text { Tier } 2 \text { Capital }}{\text { Risk Weighted Assets }} \times 100 \%
$$

\section{RESEARCH METHODS}

This study uses a system development approach, the Waterfall method. The stages of system development will be divided into work activities into a gradual and ongoing process from one another [44]. System development will be carried out using an object oriented approach, with 3 (three) main stages, namely the object oriented analysis (OOA) stage, object oriented design (OOD) and object oriented programming (OOP) [45,46]. Starting with the steps to find out the information needed or determine the needs of the system to be built through the OOA stages. The results will be presented in several object-oriented models using UML (Unified Modeling Language). Followed by the OOD stage, namely the determination of the system component design. In this design, the components that will build the system and its interactions with others will be described. The OOP stage, which is the system development stage, works based on the results of this system design. The system is built by translating the system design into a program using a specific programming language [47-49]. In this research, VB.Net 2012 and MySQL programming languages are used as a database for collecting data from the system.

\section{RESULTS AND DISCUSSION}

Theoretically, the measurement of the health of financial institutions, especially LPDs can be done at any time. This is increasingly possible if the LPD has made a record based on a computerized information system. The existence of this information system will certainly allow and facilitate the issuance of LPD financial reports at any time and certainly up to date. The availability of data for ratio calculation is not a problem in the LPD. LPD already has a good bookkeeping system, so that financial data in the form of income statements, balance sheets and credit developments are definitely available. Equipped with the results of self-assessment related to LPD management, the determination of LPD health level by the RGEC method can be carried out. Broadly speaking, the appropriateness of the LPD health level can be done based on the factors and weighting of the assessment as in Table 1.

From the sum of the ranking values of the components taken into account in determining the level of LPD soundness, a composite ranking calculation using (6) is then performed. The results obtained are then matched into Table 2 to determine the level of LPD health [50].

$$
\text { Composite Rating }=\frac{\text { Sum of Composite Values }}{\text { Total Overall Composite Rating }} \times 100 \%
$$


TABLE I. COMPONENTS AND DETERMINANTS OF LPD HEALTH

\begin{tabular}{|c|l|l|l|l|l|l|l|}
\hline \multirow{2}{*}{$\#$} & \multirow{2}{*}{ Component } & \multirow{2}{*}{ Ratio/Period } & \multicolumn{5}{|c|}{ Rating } \\
\hline \multirow{2nnnyyyy}{*}{1} & \multirow{2}{*}{ Risk Profile } & NPL & $\mathbf{1}$ & $\mathbf{2}$ & $\mathbf{3}$ & $\mathbf{4}$ & $\mathbf{5}$ \\
\hline & & LDR & & & & & \\
\hline \multirow{2}{*}{2} & $\begin{array}{l}\text { Good Corporate } \\
\text { Governance }\end{array}$ & Semester 1 & & & & & \\
\hline & Semester 2 & & & & & \\
\hline \multirow{2}{*}{3} & Earnings & ROA & & & & & \\
\hline & NIM & & & & & \\
\hline 4 & Capital & CAR & & & & & \\
\hline Composite Value (35) & & & & & & \\
\hline
\end{tabular}

TABLE II. DETERMINATION OF LPD HEALTH LEVEL

\begin{tabular}{|l|l|l|}
\hline \multicolumn{1}{|c|}{ Weight $(\%)$} & $\begin{array}{c}\text { Composite } \\
\text { Rating }\end{array}$ & \multicolumn{1}{|c|}{ Health level } \\
\hline $86-100$ & CR 1 & Very healthy \\
\hline $71-85$ & CR 2 & Healthy \\
\hline $61-70$ & CR 3 & Healthy enough \\
\hline $41-60$ & CR 4 & Unhealthy \\
\hline$\leq 40$ & CR 5 & Not Healthy \\
\hline
\end{tabular}

Referring to the description above, it can be modeled the needs of the system to be built as presented in Figure 1. The system built will be able to be operated by two groups of users, namely normal users and users of LPD health assessors. Ordinary users are users whose duty is to input various kinds of data into the system, both data related to LPD operations and related to self-assessments related to LPD management. Whereas the user evaluator is the LPD management and supervisory team, with an interest in the health level of the LPD.

There are 2 (two) types of data that must be provided by users into the system, namely financial statements and selfassessment results related to LPD management. The financial statements that must be provided consist of an income statement, balance sheet and LPD credit developments. LPD health assessments will be carried out by calculating various ratios, according to the components outlined in Table 1 .

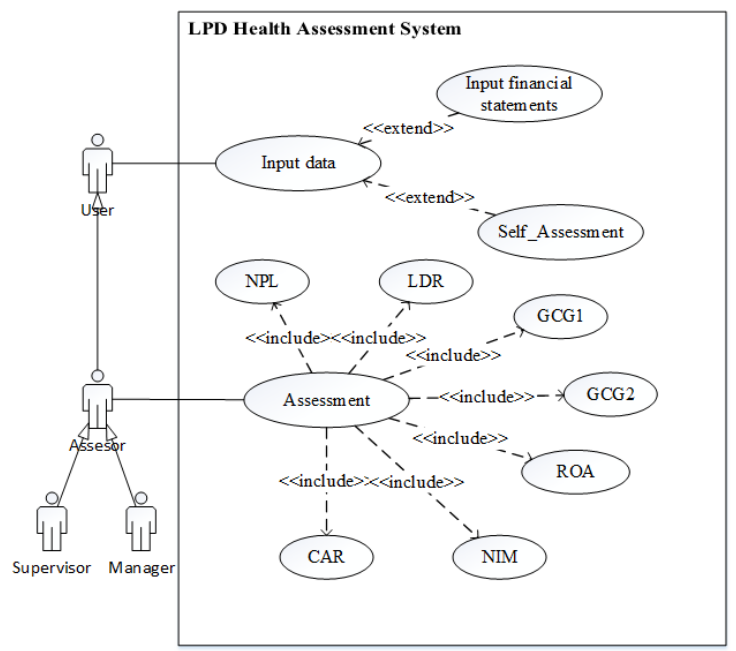

Fig. 1. Use case for the LPD health assessment system.

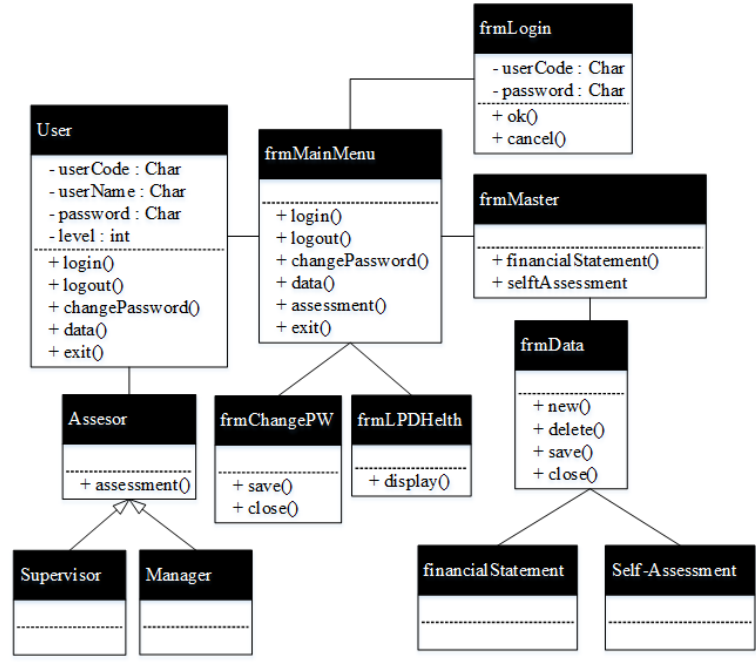

Fig. 2. The system design class diagram.

After obtaining the results of the analysis, the system development stage can be continued with the system design stage. The system design is carried out by referring to the results of the analysis that has been made previously. In the OOD stage, the system design is made in the form of a Design Class Diagram. The design of this system is presented in Figure 2.

As shown in Figure 2, the LPD health level assessment system will be built on twelve classes. In accordance with the results of the analysis described earlier, the system will be operated by two user categories. Users will be distinguished by the value of the level, which is 0 or 1 . Level 0 is intended for normal users, while level 1 is for evaluating users. Each user will have a userCode, userName and password. When the user will operate the system, it must start by logging in. The login process is done by typing the userCode and password from the user who will operate the system. If appropriate, the user can operate the system according to its category. Each user can make changes to their password and input data. Whereas specifically for the User Assessor, which consists of the Supervisor or Manager, can carry out the assessment function, to determine the health level of the LPD. To end the operation of the system, the user can log out or exit. Logout to end the operation of the system, but the system is still running, while exiting at the same time to close the system.

To facilitate operation, the system built will be equipped with a number. These menus will be handled by the frmMainMenu class. The menu provided is tailored to the needs of the user, including Login, Logout, Change Password, Data, Assessment and Exit. The existence of the Assessment menu can only be selected / operated by the Accessor user. When the new system is activated, only two menus will be active, namely Login and Exit. To operate it, the user must select the Login menu, by entering the userCode and password. The login process, which determines whether or not a user can operate the system, is handled by the frmLogin class. Users are allowed to enter the system if the user can enter a valid 
userCode and password. Next, the system will activate a menu that matches the user category, as explained earlier. If deemed necessary, the user can change the password. Password change is done by filling in the old password and new password. This password change process will be handled by the frmChangePW class. The process of inputting data which includes data on Financial Statements and Self-Assessment will be handled by the frmMaster class. Inputting financial statement data will include income statement data, balance sheet and credit developments. The overall data input is then handled by the frmData class.

The data used to determine the LPD health will be stored in a database. The data includes data on company income, balance sheets, credit developments and management opinions. Each data will be stored in a table of Profit and Loss, Balance Sheet, Credit Development and Self-Assessment. This stored data can still be manipulated (add, edit or delete), to match the current conditions.

User assessors can determine and view the health level of the LPD by selecting the Assessment menu. The system will follow up by performing calculations based on the previously entered data. The system will determine the level of health of the LPD in accordance with the provisions previously explained. As shown in Figure3, in addition to showing the cumulative level of LPD health, the system also displays the health level for each component of RGEC.

In Figure 3, it can be seen that the system built from this study has been able to present the LPD health level. This level of health can be presented anytime, quickly and accurately, of course, based on the data provided by the system. The level of health is presented in detail, based on the assessment component in the RGEC method. In addition to being able to know the overall health level, displaying the health level per component will of course be very useful for the LPD management or supervisor team. They will be able to determine the focus of attention to the existing components or factors, especially if something goes wrong. Improvements in the performance of each component will of course increase the health level of the LPD.

The existence of this system in the LPD will certainly greatly ease the burden on the supervisory team in supervising the performance of LPD managers. LPD health monitoring can be carried out at any time, without having to wait for manual reports from the LPD management team. This system will be far more perfect if it is operated in an integrated manner with the existing financial information system. This integration will make the data needed by the system up to date.

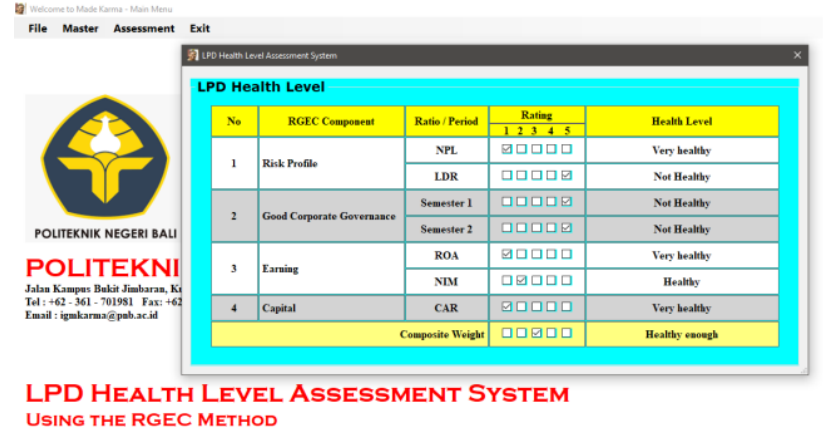

Fig. 3. LPD health level.

\section{CONCLUSION}

The system built was able to conduct an assessment of the health level of the LPD by using the RGEC method. The soundness of LPD is determined based on ratio calculation according to the components in the RGEC method, with their respective determinants weights. In addition to displaying the overall level of LPD health, the level of achievement per component is also displayed, making it easier for the manager or supervisor to conduct LPD performance analysis in more detail

\section{ACKNOWLEDGMENT}

The author would like to express his gratitude to the Director of the Bali State Polytechnic and the Chair of the Bali State Polytechnic P3M who have provided grants to finance this research. To Mr. I Made Ariana, SE., M. Si, Ak and Mr. I Ketut Suwintana, S. Kom, MT., Thank you for their guidance, direction and input during the implementation of this research.

\section{REFERENCES}

[1] J.H. Wijaya, E.M. Utami, and M.H.M. Saudi, "Effect of bank health level (Using rgec method) on profit growth," Int. J. Psychosoc. Rehabil., 2020

[2] L.A. Stella and R. Puspitasari, "Analysis of Bank Rating with RGEC Method Case Study at PT Bank Mandiri (Persero) Tbk for the Period 2013-2017,", 2020.

[3] B. Gunawan and K.M. Arvianda, "Bank Health Level Analysis Using CAMELS and RGEC Methods on PT Bank Panin Dubai Syariah Ltd.,' in 5th International Conference on Accounting and Finance 2019 (ICAF 2019), 2019.

[4] F.J. Christian, P. Tommy, and J. Tulung, "Bank Health Analysis using RGEC Method in BRI and Mandiri Bank Period 2012-2015,” J. EMBA J. Ris. Ekon. Manajemen, Bisnis dan Akunt., vol. 5, no. 2, 2017.

[5] A. Lebbe and A. Rauf, "Towards Increasing the Financial Performance: An Application of CAMEL Model in Banking Sector in the Context of Sri Lanka,” Res. J. Financ. AccountingOnline), 2016

[6] O. Lisa and B. Hermanto, "Analysis of Risk Profile, Good Corporate Governance, Earnings, and Capital (Rgec) in Syariah Commercial Banks and Conventional Commercial Banks," Int. J. Soc. Sci. Bus., vol. 4, no. 1, pp. 58-65, 2020. 
[7] S. Sahota and B. Dhiman, "Relative performance analysis of scheduled commercial banks in India: A camel model approach," Indian J. Financ., 2017.

[8] C. Akhyar, M., . A., and G. Syamni, "Profit Growth in Indonesian Sharia Bank: the Impact of RGEC," Int. J. Eng. Technol., 2018.

[9] V.E. Candara and P.Y. Jayanto, "The Effect of RGEC Method, Management, and Cooperation Identity on The Health Level of BMT," Account. Anal. J., 2017.

[10] A. Abadi, "A new method to analyze bank performance level in Indonesia using fuzzy model," Int. Math. Forum, 2016

[11] D.P. Morgan, "Rating banks: Risk and uncertainty in an opaque industry," Am. Econ. Rev., 2002

[12] M. Permatasari and P. Sawitri, "Health Assessment of Government Banks in Indonesia using Risk-Based Bank Rating," J. Bus. Econ., 2018.

[13] R.D. Hadiwidjaja and Y. Widiastuti, "Assessing the Effect of Bank Performance on Profit Growth Using RGEC Approach," Rev. Integr Bus. Econ. Res., vol. 5, no. 3, p. 87, 2016.

[14] I. Andriyani, R.P. Mayasari, and D.S. Aryani, "Soundness Rating of Commercial Banks Before and After Implementation of RGEC Method In Indonesia," J. Keuang. dan Perbank., 2018.

[15] I. Andriyani, R.P. Mayasari, and D.S. Aryani, "Sou ndness Rating of Commercial Banks Before and After Implementation of RGEC Method in Indonesia," J. Keuang. dan Perbank., vol. 22, no. 1, pp. 162-169, 2018.

[16] Z. Zainuddin and Y. Djaelani, "Applying Risk Profile, Good Corporate Governance, Earning and Capital (RGEC) Method to Predict the Bank Health (Case Study on PT. Bank Tabungan Negara)," Accountability, 2018 .

[17] Y. Octafilia and E. Wijaya, "Study of Conventional Bank Health in Indonesia from 2012 to 2017," 2020.

[18] M.J.F. Esomar, L. Loppies, and E. Turukay, "The analysis of the influence of risk profile, good corporate governance, earning and capital (RGEC) towards the company value in the sub-sector of foreign exchange private national commercial bank which is listed on the Indonesia stock exchange (IDX)," Int. J. Adv. Sci. Technol., 2020.

[19] Y. Devianto and S. Dwiasnati, "Banking Health Assessment Using CAMELS And RGEC Methods, Using OJK's Banking Financial Statement Data," Int. J. Eng. Comput. Sci., 2018.

[20] H.D. Seibel, "Culture and governance in microfinance: Desapakraman and lembaga perkreditan desa in bali," in Microfinance in Developing Countries: Issues, Policies and Performance Evaluation, 2013.

[21] R. Misra, "Muntigunung Lembaga Perkreditan Desa, Indonesia: Village Ownership as a Model for Remote Outreach of Financial Services," 2008

[22] L. Arsyad, "Assessing Factors Affecting the Repayment Rate of Microfinance Institutions: A Case Study of Village Credit Institutions of Gianyar, Bali," Gadjah Mada Int. J. Bus., 2013.

[23] J.I. Kosasih and D. Hendrawan, "Existence of entities 'village credit institutions/lembaga perkreditan desa (Ipd)' local community in Bali viewed from financial control system in Indonesia learning from Bali local genius in increasing the local economy," Int. J. Appl. Bus. Econ. Res., 2016.

[24] L. Arsyad, "A n Assessment of Microfinance Institution Performance: The Importance of Institutional Environment," Gadjah Mada Int. J. Bus. 2005.

[25] I.G.M. Karma and N.K. Sukasih, "Designing Application for Determining the Health Level of Village Credit Institutions with the CAMEL Method," in BT - International Conference On Applied Sciece and Technology 2019 - Social Sciences Track (iCASTSS 2019), 2019.

[26] G. Gibbons, R.D. Hisrich, and C.M. DaSilva, "Financial Ratio Analysis," in Entrepreneurial Finance: A Global Perspective, 2016.

[27] P.A. Griffin, "Financial Statement Analysis," in Finding Alphas: A Quantitative Approach to Building Trading Strategies, 2015.

[28] P.P. Drake, "Financial Analysis," in Institutional Investment Management: Equity and Bond Portfolio Strategies and Applications, 2012
[29] K.E. Tuwo and F.J. Tumewu, "The Analysis of Bank Soundness using Risk-Based Bank Rating Method (RBBR) at PT. Bank SulutGo," J. EMBA J. Ris. Ekon. Manajemen, Bisnis dan Akunt., vol. 6, no. 4, 2018.

[30] D. Rahayu and S. Suhendro, "Health Analysis of Bank Mandiri and Bank BCA with RGEC Method 2010-2014.," J. IIm. Wahana Akunt., vol. 11, no. 1, pp. 1-14, 2016.

[31] L.A. Africa, "Financial Distress Prediction Using RGEC Model on Foreign Exchange Banks and Non-Foreign Exchange Banks," J. Account. Strateg. Financ., vol. 2, no. 1, pp. 48-55, 2019.

[32] R.G. Mais and D.I. Sari, "Evaluation of banks health rate of Indonesia and Malaysia Islamic bank with RGEC method," Int. J. Appl. Bus. Econ. Res., 2015.

[33] R. Prihatni, "Effect of risk profile, good corporate governance, earnings, and capital on growth income in banking services listed in Indonesia stock exchange," Acad. Account. Financ. Stud. J., 2019.

[34] Y. Anwar, "Comparative Analysis Of Commercial Banks Goverment Owned And Private Banks National Using RGEC," Account. J. Binaniaga, 2016.

[35] Azeharie, W. Marcellina, Wahjono, and S. Imam, "Analysis of Bank Health At Indonesia State Owned Bank Using Rgec Method At Bbri Bbni and Bank Mandiri for Periods 2011-2015," Int. Conf. Inf. Technol. ad bussiness, 2017.

[36] R. Piu, S. Murni, and V. Untu, "Analisis Banking Comparison Healt By Using The Method RGEC The Bank Book Four Conventional Public," J. EMBA, 2018

[37] W. Marcellina and S. Imam, "Analysis Of Bank Health At Indonesia State-Owned Bank Using Rgec Method At Bri, Bni, And Bank Mandiri For Periods 2011-2015," in Prosiding International conference on Information Technology and Business (ICITB), 2018, pp. 70-76

[38] A. Hendratmi, P.S. Sukmaningrum, and F.F. Hasib, "Comparative Analysis between Islamic Banks in Indonesia and Malaysia Using RGEC Method and Sharia Conformity Indicator Period 2011-2015," 2018

[39] A. Farhan and S. Safira, "Analysis of Bank Soundness with RGEC Method (Risk Profile, Good Corporate Governance, Income and Capital)," 2020.

[40] N. Nadirsyah, M. Indriani, D. Dinaroe, and I. Fadhliati, "Study of Banks' Performance by Using RGEC (Risk Profile, Good Corporate Governance, Earnings, and Capital) Method," Proc. AICS -Social Sci., vol. 8, pp. 55-66, 2018.

[41] D. Nicola, S. Manalu, and T.M.H. Hutapea, "Effect of Bank Soundness Level RGEC Method on Index of Financial Inclusive in Indonesia," J. Apl. Manaj., 2017.

[42] A. Karim, W. Rachmawati, and R. Widyaswati, "The Analysis of Sharia Banks Soundness Level Using Rgec Method," Econ. Bus. Solut. J., 2018.

[43] A. Hayes, "Capital Adequacy Ratio - CAR," 2020. [Online]. Available: https://www.investopedia.com/terms/c/capitaladequacyratio.asp\#: :text= a financial crisis.-, Calculating CAR, is divided into two tiers.

[44] R.S. Pressman, Software Quality Engineering: A Practitioner's Approach. 2014

[45] C. Larman, Applying UML and Patterns: An Introduction to ObjectOriented Analysis and Design and the Unified Process (2nd Edition). 2001 .

[46] J. Whitten and L.D. Bentley, Systems Analysis and Design Methods. McGraw-Hill Education, 2007.

[47] M. Boggs and W. Boggs, Mastering UML with Rational Rose 2002 Alameda, CA, USA: SYBEX Inc., 2002.

[48] E. Kindler and I. Krivy, "Object -oriented simulation of systems with sophisticated control," Int. J. Gen. Syst., vol. 40, no. 3, pp. 313-343, 2011

[49] J. Rumbaugh, I. Jacobson, and G. Booch, Unified Modeling Language Reference Manual, The (2Nd Edition). Pearson Higher Education, 2004.

[50] A.H. Romdhoni, H. Samanto, and N. Hidayah, "Analysis of Bank Soundness Rating with Risk Profile, Good Corporate Governance, Earning and Capitalization (RGEC) Methods at BRI Syariah Bank Inc.,' Int. J. Islam. Econ. Bus. Manag. Emerg. Mark., pp. 11-22, 2020. 